\title{
Global Miljøstyring av \\ Olje- og Gassaktiviteter i \\ Arktis: Et institusjonalisert \\ samarbeid eller en uformell \\ dialog?
}

Aase Refsnes cand.merc.pol., email: aarefsnes@gmail.com

Et isfritt Arktis har åpnet for økt olje- og gassaktivitet. Artikkelen ser på hvilke styringsmekanismer som blir tatt i bruk for å beskytte det sårbare miljøet. Her er det ikke de formelle, men snarere de uformelle multiaktørsamarbeid som lyder lovende.

\section{Introduksjon}

De siste årene har situasjonen i Arktis tiltrukket seg enorm oppmerksomhet. Konsekvensene av global oppvarming merkes spesielt i Arktis, hvor temperaturene har steget mye hurtigere enn i resten av verden. Massiv is-smelting har åpnet for økt menneskelig aktivitet, inkludert olje- og gassvirksomhet. Ifølge US Geological Survey er slike aktiviteter forventet å øke i tråd med at 24 prosent av de resterende uoppdagede olje- og gassressurser antas å befinne seg i Arktis. Dessverre medfører $ø$ kt olje- og gassaktivitet stor risiko for det sårbare marine miljø i regionen, og nødvendiggjør at global styring av virksomheten bør ha høy prioritet.

Såkalte "globale styringsteoretikere" framhever det økende antall ikke-statlige aktører involvert i globale styringsprosesser. Næringslivsaktører, slik som multinasjonale selskaper, har fått stadig større innflytelse i den globale styringen av våre felles problemer. Globale styringsteoretikere som Mikael Wigell (2008), Karin Bäckstrand (2006), samt Marie-Laure Djelic og Kerstin Sahlin-Andersson (2006) understreker at slike multiaktør-samarbeid ofte skjer mellom ulike statlige og ikke- statlige aktører. Andre globale styringsteoretikere, som Morten Ougaard og Anna Leander (2010) anser multiaktører som en viktig del av globale styringsmekanismer og betrakter ofte slike samarbeid mellom næringslivet, andre ikke-statlige aktører og offentlige institusjoner som løsningen på mange globale problemer. Spesielt for globale miljøspørsmål som ofte ikke har geografiske grenser, ser global styringsteoretikere på multiaktør-samarbeid som en sentral mekanisme for å skape bedre styring.

Min agenda har vært å undersøke i hvor stor grad private næringslivsaktører og offentlige institusjoner samarbeider i styringen av de økende miljøutfordringene man møter gjennom olje- og gassaktivitet i Arktis. Som studietilfelle ("case") har jeg valgt samarbeidet mellom oljeindustrien og Arktisk Råd. Som en del av undersøkelsen vil jeg analysere hvorvidt dette samarbeidet kan karakteriseres som institusjonalisert eller uformelt. Gjennom fire dybdeintervjuer med nøkkelaktører og via dokumentanalyse av sentrale rapporter fra Arktisk Råd, individuelle olje-selskaper og "International Association of Oil and Gas Producers (OGP)“, om miljøutfordringene i Arktis, har jeg fått tilgang på relevante data som har bidratt til min analyse.

Denne artikkelen er strukturert på følgende måte. Først vil jeg beskrive global styring i Arktis; deretter global styring og betydningen av multiaktør-samarbeid, før jeg beskriver kort det analytiske rammeverket jeg tar i bruk. Jeg beskriver så hovedfunnene som jeg har kommet frem til før jeg avslutter med min konklusjon. 


\section{Global styring i Arktis}

Det er flere faktorer å ta i betraktning når man vurderer styringssituasjonen i regionen. Den Arktiske region blir som oftest definert som det geografiske området nord for Polarsirkelen. Siden kun Danmark, Norge, USA, Canada og Russland har Arktisk kystlinje, står de i en særskilt situasjon til å styre havområdene i regionen ${ }^{1}$. Men nylig har de territorielle havgrensene i Arktis blitt satt på dagsorden, mye grunnet de forventede olje- og gassressursene i regionen. Samtidig peker rapporter, slik som "Intergovernmental Panel on Climate Change (IPCC: 2007)" og "The Arctic Climate Impact Assessment (ACIA 2004)", på at regionen kan bli isfri i store deler av sommersesongen om kun få tiår. Denne smeltingen vil skape økt tilgjengelighet for menneskelig aktiviteter, både innen olje- og gassområdet og shipping ${ }^{2}$, samt fiske og turisme. Selv om det store "gullrushet" 3 ennå ikke er en realitet, åpner reduksjonen i hav-is for mange muligheter.

Det har de siste årtier vært en økende internasjonal verdsettelse av sårbarheten til miljøet i Arktis. Den norske nordområdeeksperten Kristine Offerdal (2007) understreker at det i sårbare, marine arktiske miljø, er sannsynlig at konsekvensene av oljeforurensing vil være både mer alvorlige og mer vedvarende enn i andre områder. ArcticOil-and-Gas (2007), en rapport utgitt av Arktisk råd, understreker at faktorer slik som lavt biologisk mangfold og langtlevende organismer bidrar til denne sårbarheten. Hvis olje- og gassaktivitetene når det nivået som er anslått, vil denne utviklingen kunne bidra til enorme miljøødeleggelser i regionen ifølge Arktisk Råd og Offerdal (2007). Erfaring fra oljekatastrofer slik som "Exxon Valdez" og "Deepwater Horizon-ulykken" ${ }^{\text {"4 }}$, har vist de alvorlige miljøkonsekvensene oljekatastrofer kan medføre.

Det er mange risiki og utfordringer som møter oljeog gassindustrien i Arktis. Oljeutslipp utgjør den største trusselen for det Arktiske miljø, men også tungmetaller, opphopning av miljøgifter i næringskjeden, samt uttynning av ozonlaget og klimaendringer bidrar til risikobildet. Både "ACIA-rapporten (2004)" og rapporten "ArcticOil-and-Gas (2007)“" vektlegger at olje- og gassaktiviteter $\mathrm{i}$ isdekkede farvann er utfordrende, mye på grunn av en grunnleggende mangel på strategi, kapasitet og teknologi for effektiv opprydning og begrensning av oljesøl. Også direktøren for AMAP, en sentral arbeidsgruppe i Arktisk Råd rundt olje- og gasstemaet, Mr. Reiersen, vektlegger at det ikke eksisterer noe oljevernberedskap som kan håndtere oljeforurensing i områder som er isbelagt. Andre faktorer, som avstand til fastlandet og ekstreme værforhold kan gjøre at oljeforurensing får spesielt store miljøkonsekvenser i Arktis. IuIie Aslaksen og Solveig Glomsød (2006), norske statistikere, peker på at økende issmelting fører til mer flytende is, som kan skade olje- og gassanlegg. Mr. Reiersen, vektlegger også slike problemer i forbindelse med de nylige olje- og gassaktivitetene på Vest-Grønland, ettersom isfjell som faller i havet kan skape problemer for oljeplattformer og potensielt fà store følger for miljøet.

Derfor, hvis olje- og gassaktivitetene når de anslåtte nivåene, vil utviklingen i følge "Arctic-Oil-an-Gas" (2007) kunne medføre alvorlige miljøkonsekvenser i regionen. Offerdal (2007) understreker synspunktet at de nye menneskelige aktivitetene i regionen krever ekstra strenge reguleringer for å ta vare på miljøet. De to forskerne i arktisk juss Timo Koivurova og Erik J. Molenaar (2009) fremhever at styringsmekanismer som kontrollerer olje- og gassaktivitetene er avgjørende for en bærekraftig utvikling i regionen. Andre juridiske forskere, slik som Linda Nowlan (2001) vektlegger at nasjonal lovgivning er et viktig redskap i å styre miljøet i Arktis, men at det eksisterer store forskjeller i slik nasjonal miljølovgivning 5 . Offerdal (2007) understreker at den strategiske betydningen av olje- og gassressurser har ført til motvilje blant de involverte statene i å innføre bindende lovgivning på miljøområdet. Så dermed, hvordan styres disse aktivitetene i Arktis slik at vi kan sikre en bærekraftig utvikling av olje og gass i regionen? Styres aktivitetene på grunnlag av institusjonaliserte ordninger og samarbeidsmekanismer eller er det en tilfeldig, ad. hoc styring som er dominerende?

Et av de globale rammeverkene som styrer miljøet i Arktis er FNs Havrettskonvensjon. Konvensjonen styrer rettighetene og ansvar over havressursene og aktivitetene både under og over havet, inkludert beskyttelse av det marine miljøet. Selv om Offerdal (2007) understreker at bestemmelsene rundt olje- og gassaktiviteter er relativt generelle, understreker de fem Arktiske kyststatene gjennom Illussat Deklarasjonen i 2008 at havrettskonvensjonen er et omfattende juridisk rammeverk og at den dekker beskyttelse av det marine miljøet, inkludert isdekkede områder. Scott G. Borgerson (2008), en amerikansk Arktisk-ekspert derimot, vektlegger at den unike geografiske situasjonen i Arktis gjør at havretten ikke kan brukes fullkomment i regionen.

Arktisk Råd er en aktør som står sentralt i å styre olje- og gassaktivitetene i regionen. Arktisk Råd er et mellomstatlig samarbeid, og de Arktiske statene er medlemmer. Arktisk råd inkluderer også urbefolkningsgrupper og observatører. Hovedmålet til Rådet er å fremme miljøvern i de Arktiske områdene. Arktisk Råd skiller seg fra Havrettskonvensjonen ved å ikke ha noen bindende juridisk myndighet. På tross av at Arktisk Råd ikke har noen spesielle håndhevingsmekanismer, understreker Kristine Offerdal (2007) at det er sannsynlig at Rådet utøver stor innflytelse over de Arktiske statene. Arktisk Råd har aktivt fokusert på miljøfarene rundt olje- og gassaktivite- 
ter. Politikken er representert gjennom "Arctic-Oil-andGas-2007“, som helhetlig har vurdert miljøaspektene ved olje- og gassaktiviteter i regionen. Arktisk Råd har også vektlagt minstestandarder for olje- og gassaktiviteter for å beskytte det marine miljøet, gjennom rapporten "Arctic-Offshore-Oil-and-Gas-Guidelines". Retningslinjene spesifiserer standarder og tilnærminger som er knyttet til OSPAR-konvensjonen. OSPAR er et regionalt, bindende regime hvor stater samarbeider om det marine miljøet i den nordøstlige delen av Atlanterhavet. Selv om Offerdal vektlegger at OSPAR er en av de mest sentrale internasjonale avtalene som adresserer marin forurensing i regionen, dekker konvensjonen bare begrensede deler av regionen.

Koivurova og Molenaar (2009) argumenterer for en generell mangel på helhetlige regelverk for olje- og gassaktivitetene i Arktis, ettersom intet rammeverk gir full dekning av aktivitetene. Andre har stilt spørsmålet om det bør utvikles et enkelt, helhetlig juridisk rammeverk for miljøvern i Arktis. Selv om Linda Nowlan (2001) antyder at en egen avtale kunne spilt en sentral rolle i å fremme bærekraftighet i Arktis, vektlegger Olav Schram Stokke (2007), en norsk forsker med hovedfokus på Arktisk, at en slik bindende avtale ikke ville bedre miljøstyringen i regionen. Stokke peker på at den beste styringsmekanismen er en fleksibel tilnærming, som inkluderer de eksisterende aktørene i Arktis. De sistnevnte forskerne samt initiativtakerne til "The Arctic Governance Project" (Corell et.al 2010), peker alle spesielt på Arktisk Råd som en viktig aktør for å bedre miljøstyringen i regionen. Videre kan man høre på Stokke (2007) som understreker avhengigheten av et godt fundamentert samarbeid mellom de involverte aktørene.

\section{Global Miljøstyring og Multiaktør-samarbeid}

Global styringsteori vektlegger betydningen av hvordan nye aktører i økende grad bidrar til å styre våre felles globale spørsmål. Global styringsteori peker på at dagens globale situasjon krever kreative styringsmekanismer som åpner for samarbeid mellom ulike aktører. Særlig i miljøspørsmål, som ofte ikke kan begrenses geografisk, står multiaktør-samarbeid sentralt. Charlotte Streck (2002), ekspert på juridiske og politiske perspektiver rundt klimaendringer, understreker at dette skyldes at de tradisjonelle styringsmekanismer ikke har gitt de ønskede resultatene innenfor global miljøbeskyttelse. Spesielt private næringslivsaktører er blitt pekt ut som sentrale partnere i globale styringsmekanismer. Den globale styringsteoritikeren Mikael Wigell (2008) understreker viktigheten av multiaktør-samarbeid hvor offentlige institusjoner og private aktører går sammen i felles fora for å engasjere seg i konsensus-orientert problemløsning. Ifølge Benedikte Bull (2010), som fokuserer på offentlige-private partnerskap i FN, blir næringslivsaktører stadig viktigere partnere i samarbeid med offentlige myndigheter, enten via staten eller internasjonale institusjoner. Selv om det eksisterer flerfoldige forskjellige typer samarbeid mellom offentlige og private aktører, er "offentlig-privat partnerskap og "globale politikknettverk" de mest vanlige multiaktør-styringsmekanismene. Både Bäckstrand (2008) og Bull (2010) peker på at offentlig-private partnerskap, hvor det offentlige og det private går sammen i frivillige samarbeidsforhold, har blitt et sentralt redskap i global styring. Også globale politikknettverk tiltrekker seg faglig oppmerksomhet som en ny type styringsmekanisme som inkluderer både offentlig og privat sektor. Disse nettverkene er ansett som åpne, fleksible og transparente strukturer etablert rundt et felles problem. Mikael Wigell (2008) peker på nettverk slik som "World Commisison on Dams (WCD), som et eksempel på hvordan multiaktør-samarbeid kan være løsningen på komplekse problemer.

De to globalstyring-forskerne Tanja A. Börzel \& Tomas Risse (2001) argumenterer for at begge de nevnte multiaktør-samarbeidene mellom det offentlige og det private er basert på forhold som kan kategoriseres som institusjonaliserte samarbeid (gjennom klare samarbeidsrelasjoner, som klart medlemskap i nettverk eller formelle partnerskap). Majoriteten av styringsteoretikerne vektlegger ikke nødvendigvis institusjonaliserte forhold, men klare vedvarende samarbeidsstrukturer, gjennom partnerskap, slik som Bäckstrand (2008) og Bull (2010) eller globale politikknettverk, som Wigell (2008). Selv om fleksibilitet i samarbeidet mellom aktørene er vektlagt blant styringsteoretikerne, er det bakenforliggende et ønske om et institusjonalisert samarbeid, ettersom det på ingen måte er ønske om et ad.hoc basert samarbeid. Også styringsteoretikerne Boström og Hallström (2010), vektlegger viktigheten av multiaktør-samarbeid i å lage politikk gjennom standarder for å lage bedre sosial og miljøvennlig adferd blant næringslivsaktører. Men selv om denne typen samarbeid kan bidra til makt til ikkestatlige aktører, bekymrer Bostöm og Hallström seg over den skjøre myndigheten slike samarbeidsmekanismer har og hvordan problemer og dynamikk rundt deltakelse kan skje på den transnasjonale arena. Dette peker også på betydningen av at multiaktør-samarbeidene er institusjonaliserte. Med bakgrunn i denne styringsteorien kan det derfor forventes å observere et institusjonelt samarbeid gjennom klare samarbeidsmekanismer, partnerskap og politikknettverk i global miljøstyring i Arktis.

\section{Rammeverk}

For å undersøke om vi kunne finne et institusjonalisert samarbeid mellom de ulike aktørene, ble det brukt en kombinasjon av to modeller. Den første og viktigste er ba- 
sert på "politikk-dialogmodellen", som er en av hovedmodellene presentert i en rapport til Generalforsamlingen i de Forente Nasjoner (FN) angående samarbeid mellom partnere i privat sektor og organisasjonen. I denne modellen skiller FN tydelig mellom uformelle og formelle samarbeidsstrukturer mellom private aktører og FN. Samarbeidet varierer i deltakelse, engasjement, omfang og formalitet og inkluderer alt fra fullt formelt institusjonell deltakelse til uformelle dialoger og workshoper. Selv om FN er en kompleks organisasjon, bruker jeg denne modellen for å skille mellom formelle og uformelle samarbeidsstrukturer mellom internasjonale institusjoner og private forretningsaktører.

Jeg fundamenterer skillet mellom institusjonelt og ikke-institusjonelt basert på hvordan FN velger å skille mellom formelt og uformelt samarbeid. Dette relaterer jeg til hvordan Oran Young, Arktis-ekspert og styringsteoretiker, nettopp bruker formelle og uformelle strukturer når han skiller mellom institusjonalisert og ikkeinstitusjonalisert samarbeid. Institusjonelle styring - og samarbeidsmekanismer er i henhold til Young basert på anordninger som bygger på formelle avtaler, mens ikkeinstitusjonelle styrings- og samarbeidsmekanismer er basert på sosiale praktiser med uformelle og uskrevne regler og normer. Ut i fra en slik teoretisk definisjon, vil formelle og uformelle modellstrukturer, bidra til å bygge opp om eksistensen av institusjonelle eller ikke-institusjonelle samarbeidsmekanismer.

Også formelle og uformelle samarbeid gjennom globale politikknettverk og frivillige standardiseringsinitiativer er inkludert i "politikk-dialog modellen". Selv om globale politikknettverk ofte karakteriseres som uformelle, og frivillige standardiseringsinitiativer som formelle, blir det for mange av disse ordningene omvendt når det er snakk om samarbeidsmekanismer. Samarbeide er et vidt konsept. Filosof og samarbeid-ekspert Raimo
Tuomela (1993) vektlegger viktigheten av "felles handling" som essensen i samarbeid, hvor flere aktører deler en "vi-holdning" som inkluderer et felles gode, tanke eller lignende og handler på grunnlag av denne vi-holdningen. Men han understreker også at samarbeid også kan inkludere felles intensjoner, slik som når biler velger å følge felles trafikkregler, selv når det ikke er en direkte felles handling.

Globale politikknettverk er på mange måter uformelle, hvor de i en større politikksammenheng ofte består av at uskrevne regler og normer. Men i lys av det å faktisk analysere samarbeid, gjør det klart at samarbeidet i seg selv i stor grad er formelt. Det er snakk om en "felles handling", gjennom deltakelse og medlemskap i allianser og globale politikknettverk, og med felles formelle politikklinjer gjennom felles erklæringer, og andre politiske utfall av samarbeid. Frivillige standardiseringsinitiativer, som inkluderer retningslinjer og prinsipper derimot, er tydelig uformelle samarbeidsstrukturer. Den generelle standardiseringslitteraturen fremmer ofte at slike initiativ er formelle, ettersom det inkluderer felles intensjoner, selv om det ikke er en direkte felles handling. Men selv om organisasjoner som den Internasjonale Organisasjonen for Standardisering (ISO) lager standarder som både offentlige og private aktører følger, er majoriteten av retningslinjer som lages, utviklet av en aktør om sin egen sosiale eller miljøvennlige aktivitet. Derfor vil hovedsakelig frivillige standardiseringsinitiativ kategoriseres som uformelle, men med visshet om at hvis aktørene tydelig følger hverandres standarder eller andre uavhengige standarder, kan dette oppfattes som formelt samarbeid ettersom slik samarbeid da er forankret i konkrete skriftlige dokumenter. Jeg har brukt elementene i "politikkdialogmodellen", til å avgjøre om vi er vitne til et formelt eller uformelt samarbeid mellom Arktisk Råd og olje- og gassindustrien.

Tabell 1. Politikk-dialog samarbeid

\begin{tabular}{|c|c|}
\hline Formelle Mekanismer for Deltakelse i Politikk-Dialog & Uformelle Mekanismer for Deltakelse i Politikk-Dialog \\
\hline $\begin{array}{l}\text { - Full deltakelse i internasjonale institusjoner } \\
\text { - Formell konsulentstatus hos den internasjonale institusjonen } \\
\text { - Deltakelse i komiteer og arbeidsgrupper i konkrete spørsmål } \\
\text { - Akkreditering på konferanser og hendelser } \\
\text { - Medlemmer av nasjonale delegasjoner på multilaterale konferanser på proble- } \\
\text { mområdet } \\
\text { - Observatørstatus eller deltakelse på møter }\end{array}$ & $\begin{array}{l}\text { - Parallelle hendelser til internasjonale konferanser } \\
\text { - Uformelle konsultasjoner, dialoger og "workshops" mellom den internasjo- } \\
\text { nale institusjonen og private aktører på konkrete politikkspørsmål }\end{array}$ \\
\hline Globale Politikk Nettverk & Frivillige Standardiseringsinitiativer \\
\hline $\begin{array}{l}\text { - Multiaktør-, partnerskapsbaserte styringsnettverk og politikkdialog } \\
\text { - Fokus på et konkret globalt problem eller spørsmål } \\
\text { - Forskjellige former for hierarki } \\
\text { - Vidt medlemskap }\end{array}$ & $\begin{array}{l}\text { - Eksistens av frivillige standardiseringsinitiativer } \\
\text { - Enten offentlig eller privat drevet } \\
\text { - Inkluderer retningslinjer om atferd }\end{array}$ \\
\hline
\end{tabular}

Kilde: FNs Generalforsamling 2001 inkludert egen plassering av globale politikknettverk og frivillige standardiseringsinitiativer. 
Elementene som beskriver de formelle og uformelle karakteristika, er beskrevet i tabell 1 .

I tillegg til politikk-dialogmodellen, har jeg brukt graden av gjensidig litteraturreferering mellom de involverte aktørene for å evaluere om vi finner et institusjonalisert samarbeid eller ei. Jeg analyserte i hvor stor grad Arktisk råd og olje- og gassindustrien refererte til hverandre i sine hovedpolitikk-dokumenter, ved å skille mellom et formelt og uformelt referansenivå.

Via politikk-dialogmodellen og referansenivået har jeg evaluert om vi har holdepunktet for et institusjonalisert samarbeid. Ved å bruke denne definisjonen og skilnaden, bruker jeg derfor forskjellen mellom formell og uformell til å skille mellom institusjonalisert og ikkeinstitusjonalisert samarbeid. Dette vises i figur 1.

Figur 1. Grad av samarbeid mellom internasjonale institusjoner og næringslivet

\section{Institusjonalisert Samarbeid \\ - Formelle Politikk-dialogmekanismer \\ - Globale Politikk- nettverk \\ - Formelt Referansenivå \\ Ikke-institusjonalisert Samarbeid \\ - Uformelle Politikk-dialogmekanismer \\ - Frivillig Standardiseringsinitiativ \\ - Uformelt Referansenivå}

\section{Hovedfunn}

Som nevnt, er det mange som argumenterer for at i feltet bærekraftighet og global miljøstyring har utviklet seg mekanismer hvor det offentlige og private samarbeider i å løse globale problemer. Jeg vil her først presentere mine hovedfunn, før jeg vektlegger viktigheten av uformell kontakt mellom de involverte aktørene. Deretter vil jeg argumentere for at vi trenger et bedre rammeverk som inkluderer uformelle styringsmekanismer når man diskuterer global styring. Hovedfunnene mine er som nevnt basert på dybdeintervjuer med de involverte aktørene. Selv om det begrensede antallet av intervjuobjekter reduserer validiteten til resultatene, har jeg intervjuet de mest sentrale aktørene som har arbeidet med å utvikle samarbeidet mellom Arktisk Råd og olje-og gassindustrien.

\section{Manglende Institusjonalisert samarbeid}

Ved bruk av politikkdialogmodellen fant vi få tegn på formelle samarbeid mellom Arktisk Råd og olje- og gassindustrien. Blant de mest formelle mekanismene, som full eller konsultativ status, var det ingen tegn på samarbeid.
For andre formelle mekanismer, var det også små tegn på samarbeid. Via "Arctic-Frontiers" konferansen i 2008, var imidlertid både representanter fra olje- og gassindustrien og Arktisk Råd til stede og diskuterte miljøutfordringene til olje- og gassaktiviteter i regionen. Dermed er det tegn på at næringslivsaktører er blitt akkreditert på konferanser, en indikator i politikkdialogmodellen. Også gjennom deltakelse i komiteer og arbeidsgrupper, er det visse tegn på samarbeid. Selv om olje- og gassindustrien ikke er medlemmer av arbeidsgruppene til Arktisk Råd, vektlegger OGP et nært forhold med disse arbeidsgruppene, spesielt "Protection of the Arctic Marine Environment (PAME)“. I tillegg har olje- og gassindustrien bidratt ved å kommentere politikkdokumenter fra både PAME og "Arctic Monitoring and Assessment Programme (AMAP)“, en annen sentral arbeidsgruppe i Arktisk Råd. Dette tyder også på at det er tegn på "deltakelse i komiteer og arbeidsgrupper". Det er også tegn på samarbeid i kategorien "medlem av nasjonale delegasjoner i multilaterale konferanser". Dette skyldes at OGP-representanter var til stede som del av den norske delegasjonen ved Arktisk Råds Ministermøte i 2009. I tillegg er det tegn på formelt samarbeid via kategorien "observasjonsstatus og deltakelse på møter. OGP har søkt om observasjonsstatus i Arktisk Råd, men søknaden er fremdeles under behandling. Men selv om det således er enkelte tegn på formelt samarbeid, er de fleste samarbeidsmekanismene preget av tilfeldige ad-hoc samarbeid, samt personlige bånd mellom de involverte aktørene. Dermed er det vanskelig å karakterisere samarbeidet som formelt. Mangelen på et etablert globalt politikknettverk og et formelt referansenivå mellom Arktisk Råd og næringslivsaktører i olje- og gassindustrien støtter videre opp om at det ikke finnes et institusjonelt samarbeid mellom de involverte aktørene.

\section{Høy Grad av Uformelt Samarbeid}

Derimot er det sterke indikatorer på et uformelt, ikkeinstitusjonalisert samarbeid. Selv om olje- og gassindustrien ikke har parallelle hendelser til Arktisk råds møter eller konferanser, er det klar tilstedeværelse av uformelle konsultasjoner, dialoger og "workshoper" mellom de involverte aktørene om miljøstyring i regionen. Både de overnevnte samarbeidsmekanismene, samt et uformelt samarbeid via frivillige standardiseringsinitiativer bidrar til en høy grad av uformelt samarbeid. Ettersom både Arktisk Råd og OGP har utviklet frivillige miljøretningslinjer for olje- og gassaktivitet, har det oppstått en uformell kontakt mellom aktørene. OGP var endog inkludert i revideringene av Arktisk Råds retningslinjer. OGP har videre tatt Arktisk Råds retningslinjer i betraktning når de har revidert sine egne miljøretningslinjer. I tillegg 
støtter det uformelle referansenivået i de primære politikkdokumentene mellom Arktisk Råd og olje- og gassindustrien opp om et uformelt, ikke-institusjonalisert samarbeid.

\section{Viktigheten av Uformelle Samarbeidsstrukturer}

Ettersom klare uformelle samarbeidsstrukturer er klart til stede i miljøstyring av olje- og gassindustrien i regionen, åpner jeg for at disse strukturene bidrar til global miljøstyring i regionen. Selv om ikke flere styringsmekanismer, inkludert uformelle, er ensbetydende med bedre styring, synes den uformelle innflytelsen i dette tilfellet å være av betydning. Uformelle møter og konferanser mellom Arktisk Råd og olje- og gassindustrien har således hatt tydelige styringseffekter. På konferansen "Arctic Frontiers" i 2008, diskuterte både olje- og gassindustrien og Arktisk Råd miljøutfordringene rundt nye olje- og gassaktiviteter og industriens perspektiver på aktivitet $\mathrm{i}$ regionen. Selv om konferansen ikke førte til bindende eller formelle avtaler, kan slike møter mellom industrien og offentlige aktører skape store styringsresultater. Det kan skje gjennom deltakelse av industriaktørene som viser velvilje til å samarbeide om miljøspørsmål, uformelle diskusjoner gjennom konferansen og ved å sette miljøstyring av olje- og gassaktiviteter i Arktis på agendaen. Gjennom slike plattformer kan de involverte aktørene gjøres klar over tilstedeværelsen og interessene til de andre aktørene. Det er mulig at slike uformelle arenaer kan bidra til at OGPs observasjonsstatus blir evaluert på en annen måte enn hvis de ikke hadde deltatt på slike uformelle møter og konferanser. Gjennom slike uformelle samarbeid kan også mer formelle nettverk mellom aktørene bli etablert og medføre mer vedvarende bånd mellom offentlige og private aktører i miljøstyringen av olje- og gassaktivitetene i Arktis. I tillegg til de uformelle møtene og dialogene skapes, både gjennom utviklingen av frivillige retningslinjer og standarder hos Arktisk Råd og OGP, samt samarbeidet i disse standardiseringsprosessene, klare styringseffekter. Disse standardene er faktisk hovedpolitikkdokumentene til både Arktisk Råd og OGP. Når det gjelder miljøstyring av olje- og gassaktiviteter i Arktis, gir kunnskap og anerkjennelse av slike retningslinjer fra de ulike aktørene viktige styringseffekter. Videre vises det at når OGP blir inkludert i workshoper i regi av Arktisk Råd og sågar bidrar i revideringen av Arktisk Råds retningslinjer, samt ved OGPs bevissthet om Arktisk Råds retningslinjer, at uformell kontakt skaper styringsresultater. Dette kunne nok ha vært enda bedre hvis Arktisk Råd i større grad hadde rettet sine retningslinjer mot industriaktører og ikke bare nasjonale myndigheter. Da ville det vært enklere for industrien å bruke disse retningslinjene aktivt i sine egne standarder og prinsipper. Uansett, siden Arktisk Råds retningslinjer bare er frivillige for nasjonale myndigheter, kan de private standardene og retningslinjene til OGP ha en stor rolle i global miljøstyring av olje- og gassaktivitetene i Arktis ved at de er mer forpliktende. Dette gjør at prinsipper som "føre var prinsippet" og "forurenser betaler prinsippet", også kan få mer betydning ved at inngår i retningslinjene til OPG, og ikke bare i Arktisk Råds retningslinjer.

Det uformelle samarbeidet som foregår mellom de to ulike miljøretningslinjene og styringsarenaene kan også ha potensiale til å utvikle seg til et mer formelt samarbeid. De nåværende samarbeidsmekanismene kan bli de første stegene til å utvikle felles retningslinjer eller følge andre eksterne standarder, hvor det vil være en "felles handling", som potensielt ville kunne bidra til store styringseffekter. Mer formell kontakt vil også kunne føre til at de frivillige standardene blir enklere å "håndheve" og gjøre det enklere å evaluere de faktiske retningslinjene. Uansett bidrar det eksisterende uformelle samarbeidet mellom retningslinjene til de involverte aktørene på en god måte til å skape global miljøstyring i Arktis.

I tillegg til å skape direkte styringseffekter, kan uformelt samarbeid mellom aktørene bidra til å skape normer når det gjelder miljøstyring av olje- og gassaktiviteter $\mathrm{i}$ Arktis, som igjen kan skape styringseffekter. Ifølge de globale styringsteoretikerne Margaret P. Karns og Karen A. Mingst (2004) er utviklingen av normer, samt normer som bakgrunn for styring en sentral del i global styring av våre felles problemer. Normer blir gjerne definert som "en standard for anstendig adferd fra aktører innen en gitt identitet" og slike definisjoner åpner for utviklingen av nye aktører, interesser og kategorier ifølge normteoretikerne Martha Finnemore og Kathryn Sikkink (1998). De karakteriserer evolusjonen og innflytelsen av normer, og har videre utviklet en normlivssyklus, som består av en trestegsprosess. De skiller mellom fremveksten av normer, aksept av normer og norminternalisering. Ved å benytte seg av et slikt rammeverk er det mulig å få innsikt i hvor mye de forskjellige fasene av normutvikling kan påvirke adferd og føre til styringseffekter. Vi kan dermed også muligens se hvordan det uformelle samarbeidet mellom Arktisk Råd og olje- og gassindustrien skaper normer. Ifølge Kenneth W. Abbott og Duncan Snidal (1998), kjente juridiske og politiske teoretikere, kan fremveksten av normer både bli påvirket av stater og internasjonale institusjoner, men også av private næringslivsaktører. Det er klart at de frivillige standardene og retningslinjene utformet av både Arktisk Råd og OGP, og den uformelle kontakten mellom disse retningslinjene, bidrar til å etablere nye normer for en bedre miljøstyring av olje- og gassak- 
tiviteter i regionen. Siden begge aktørene også lager slike retningslinjer, er det også et tegn på aksept av de etablerte normene. Dette kan føre til at andre aktører følger etter, og implementerer slike normer. En slik aksept for normer kan så i stor grad føre til styringseffekter. De frivillige standardene kan også bidra til mer spesifikke standarder som fører til bedre miljøadferd, slik som "føre var prinsippet" og "forurenser betaler prinsippet". I tillegg til at olje- og gassaktivitet i Arktis er en relativ ny utvikling, vil stor mediedekning av aktivitetene, giøre det sannsynlig at nye normer og retningslinjer vil bli utviklet. Det er nemlig bare de siste årene at Arktisk Råd, olje- og gassindustrien og andre ikke-statlige aktører har satt fokus på problematikken. Spesielt hvis olje- og gassaktivitetene når det nivået som er ventet, er det trolig at flere retningslinjer og rammeverk vil oppstå, som igjen kan ligge til grunn for etableringen av nye normer.

\section{Behov for et Bedre Rammeverk}

På bakgrunn av de potensielt store styringseffektene av uformelt samarbeid mellom de involverte aktørene, er det nødvendig at uformelt samarbeid blir inkorporert og får en større plass i multiaktør offentlig-private partnerskap. Det er tydelig en mangel i global styringsteori og multiaktør-teori at man ikke fokuserer så mye på uformelle samarbeid mellom offentlige og private aktører. Det er viktig for global styringsteori å kunne oppdage, evaluere og analysere de uformelle samarbeidsstrukturene, ettersom de både kan lage effektive styringsmekanismer og være fundamentet til mer formelt samarbeid. Hvis vi inkluderer uformelt samarbeid i likningen, er det mulig å oppdage nye samarbeidsstrukturer. Dette kan påvirke hvordan vi ser på næringslivet som partnere i global styring og hvordan uformelt samarbeid bidrar til å lage styringseffekter. Ved å inkludere uformelle strukturer, kan de også gi indikasjoner på når uformelle samarbeid utvikler seg til å bli formelle samarbeid. Det kan lære politikkaktørene å lage mer effektive styringsmekanismer. Kritikken er basert på den begrensede forklaringsevnen til formelle samarbeidsstrukturer som allerede eksisterer innenfor multiaktør- og global styringsteori sånn som "offentlig- private partnerskap" og "globale politikknettverk". Begge disse samarbeidsmekanismene er basert på avtaler om partnerskap, hvor samarbeidsforholdet er formelle gjennom medlemskap og andre prosedyrer. Hoveddelen av debatten om private aktører og deres nye rolle i global styring har vært begrenset til institusjonelle "offentlig -private partnerskap" og "globale politikknettverk" (Pattberg 2005). Det burde imidlertid også være rom for å inkludere alle "nye" former for multiaktørsamarbeid mellom offentlige og private aktører inn i multiaktørteorien. Spesielt forskere som vektlegger disse nye "nettverkene" og "multiaktørforumene" som del av global styring og viktighetene av næringslivet i global styring, bør inkorporere disse aspektene.

Det er noen teoretikere som har begynt å inkludere uformelle strukturer. Benedikte Bull (2005) åpner opp for ny forskning når hun understreker at næringslivet kan ta del i multiaktør-samarbeid gjennom mange ulike styringsformer. Også Morten Ougaard og Anna Leander (2010) benytter nye uformelle teknikker når de evaluerer samarbeidsmekanismer i global styring. De vektlegger viktigheten av "Corporate Social Responsibility (CSR)", og andre former for samarbeid mellom offentlige og private aktører. De peker på at gjennom privat standardsetting, næringslivets selvreguleringer samt CSR policy, prøver private aktører å nå de samme målene som offentlige styringsmakter innenfor sosial- og miljøspørsmål. Næringslivsaktører som fokuserer på slike prinsipper kan dermed bli ansett som en slags partner i global styring.

Andre forskere har også fokusert på uformelle samarbeidsstrukturer. De har vektlagt betydningen av frivillige standardinitiativer, slik som "UN Global Compact" og "OECD Guidelines for Multinational Corporations". Gjennom slike retningslinjer skriver næringslivsaktørene under på å følge fastlagte prinsipper og standarder. Videre, via slike standarder, vil næringslivsaktører passivt fremme den samme politikken som potensielle offentlige partnere. For eksempel har de fleste olje- og gasselskapene som opererer i Arktis skrevet under på "UN Global Compact“. Gjennom denne avtalen har olje- og gasselskapene forpliktet seg til å følge standarder som “føre var prinsippet", som også er en av hovedprinsippene i miljøretningslinjene til Arktisk Råd. Slike teoretiske bidrag kan være verdifulle i å analysere multiaktør-samarbeid sammen med private styring og CSR spørsmål som del av global styringsteori.

Også gjennom den generelle globale styringsteorien har uformelle strukturer stått sentralt. Oran Young (1997) understreker at det bør settes større fokus på samarbeid hvor statlige og ikke-statlige aktører interagerer med hverandre på mange komplekse måter. En slik kompleks kanal er gjennom uformelt samarbeid. Kommisjonen for Global Styring (1995) definerte global styring til å inkludere hvordan individer og institusjoner, både offentlige og private, styrer våre felles problemer. Kommisjonen vektlegger også at global styring som en prosess hvor diverse interesser er tatt $\mathrm{i}$ betraktning og samarbeidsmekanismer blir brukt. Dette inkluderer både formelle institusjoner, samt uformelle avtaler. Også i andre definisjoner av global styring, inngår uformelle samarbeidsstrukturer. Ifølge de kjente teoretikerne i internasjonal politikk, Robert O. Keohane og Joseph S. Nye (2000) definisjon av global styring, skjer styring via 
både formelle og uformelle prosesser og institusjoner. Rosenau (1995), en av de første teoretikerne til å sette "governance without government" på kartet, vektlegger også betydningen av både nye og institusjonelle mekanismer og regimer. Dette indikerer at han verdsetter uformelle og nylige etablerte samarbeidsmekanismer. Også Margaret P. Karns og Karen A. Mingst understreker betydningen av uformelle strukturer i global styring, selv om det er vanskelig å alltid klargjøre hva teoretikere mener med termer som "mekanismer" og "prosesser". Også teoretikere innenfor multiaktør-samarbeid, støtter i teorien opp om uformelt samarbeid. Andre teoretikere som Wolfgang Reinicke og Francis Deng (2000) peker på at global styring har hovedsakelig fokusert på formelle, etablerte politikkprosesser. Disse teoretiske definisjonene av global styring støtter at uformelt samarbeid også må bli implementert $\mathrm{i}$ en helhetlig tilnærming til global styring.

Mine funn i Arktis, samt det påbegynte teoretiske arbeid om uformelt samarbeid, støtter oppunder behovet for utviklingen av et mer helhetlig rammeverk. Dette rammeverket burde være basert på multiaktør-samarbeid og hvordan uformelle samarbeid mellom offentlige og private aktører får styringseffekter. Ettersom private næringslivsaktører også lager standarder for miljøvennlig adferd, er det viktig at disse interaksjonene blir analysert. Dette vil kunne skape en bedre, og mer effektiv måte å styre våre globale problemer på.

Et annet spørsmål er i hvilken grad dette område er nytt og om det i fremtiden vil kunne utvikle seg et større samarbeid mellom aktørene. Ettersom det på nåværende tidspunkt er lite offshore olje- og gassaktivitet i Arktiske strøk og siden det allerede finnes uformelle samarbeidsstrukturer mellom Arktisk Råd og olje- og gassindustrien, kan det tyde på at samarbeidsstrukturene er i utvikling, og at vi i fremtiden vil kunne bli vitne til mer institusjonaliserte samarbeid mellom offentlige og private institusjoner på dette området.

\section{Global Miljøstyring i Arktis vs. Global Miljøsty- ring}

Kan vi bruke erfaringen fra global styring i Arktis til å vurdere andre styringsproblemer som oppstår $i$ vår globale verden? Siden global miljøstyring av olje- og gassaktiviteter i Arktisk kun er et tilfelle, har den selvfølgelig begrenset forklaringsevne i global styringsteori. Allikevel mener jeg at erfaring fra miljøstyring av olje- og gassaktivitet i regionen kan bidra i den globale styringsdebatten. Først og fremst sier den imidlertid mye om styring $i$ Arktis. Styringen av olje- og gassaktiviteter i regionen er et nytt temaområde. Videre er Arktis i seg selv en region hvor det er lite erfaring med styring. Men den Arktiske region er bare en blant mange andre regioner, som hoved- sakelig består av vann og stater, og er styrt via både nasjonal og internasjonal lovgivning. Olje- og gassutvinning involverer også våre felles ressurser, noe som innebærer at god styring er essensielt for bærekraftig utvikling i regionen. Det er mange aktører som har interesse for regionen, noe som antyder at det er utmerkede vilkår for global styring. Dermed er det mulig at resultatene og konklusjonene fra Arktis kan bli anvendt for andre tilstøtende problemområder. Det er mulig at det også kan si noe om global miljøstyring, eksempelvis styring av andre regionale havområder og andre offshoreområder, samt også olje- og gassaktivitet på land. Globaliseringsforskerne David Held og Anthony McGrew (2002) karakteriserer global styring som et fenomen med variabel geometri og vektlegger at den politiske betydningen og reguleringskapasiteten i disse avtalene varierer betraktelig fra problem til problem og geografisk område. Dette stemmer overens med Arktis-eksperten Oran Young (1997), som observerer at kravene for å styre og løse globale problemer er forskjellige for ulike spørsmål og problemområder. Derfor, kan det hende at det geografiske området rundt Arktis, problemet med å regulere olje- og gassaktiviteter eller vanskeligheter med å styre miljøproblemer, gjør at erfaringene fra Arktis bare har delvis relevans til andre områder. Men Arktis eller miljøproblemer i olje- og gassindustrien er imidlertid ikke vidt forskjellige fra andre områder, ettersom både regionalisering og spørsmål om bærekraftighet i global styring er vanlige problemstillinger. Dette gjelder også styring av olje- og gassaktiviteter, så vel som andre ressurser. Og selv om nylige geopolitiske konflikter har oppstått rundt regionen, og gjort det vanskeligere å samarbeide, er dette også status quo i andre regioner og "konfliktområder".

Imidlertid kan noen aspekter ved global miljøstyring av olje- og gassaktiviteter i Arktis betegnes som spesielle. For det første er olje- og gassindustrien en av de største og mest lønnsomme industrier i verden. Oljeselskapene er gigantiske og har ofte større økonomier enn gjennomsnittlige industrialiserte stater. Selv om "business" er en del av global styring, er noen av disse selskapene blitt så mektige at de kan velge å løse problemet uten å samarbeide med offentlige institusjoner. For det andre, er sikkerhetsaspekter i internasjonal politikk ofte ekskludert fra global styring og ofte er det sagt at i områder rundt geopolitikk er det makt som er hoveddrivkraften. Men fremdeles argumenterer Arktis-eksperten Oran Young (1997) at i økonomiske spørsmål gir dette muligheter for gensidig gevinst og genererer derfor insentiver for samarbeid. Derfor, selv om det bare er et "case", skiller ikke de miljøproblemene vi møter i olje- og gassindustrien seg mye fra andre globale problemer. Som konsekvens, er det gode muligheter for at resultatene, bidragene og konklu- 
sjonene fra dette tilfellet dermed kan bidra til å belyse styring $i$ andre områder og regioner.

\section{Konklusjon}

Arktis er en region som gir olje- og gassindustrien spesielle utfordringer når det gjelder å beskytte miljøet. Selv om global oppvarming har åpnet opp for menneskelig aktivitet i regionen, er havet fremdeles delvis dekket av is. Sammen med et ekstremt klima gir dette ekstra miljøutfordringer for olje- og gassindustrien. Selv om det eksisterer styringsmekanismer igjennom Havrettskonvensjonen, OSPAR- konvensjonen og Arktisk Råd, er det fremdeles ikke noe regime som fullstendig dekker alle aspekter ved miljøstyring av olje- og gassaktiviteter i Arktis. Siden det marine miljø i regionen er veldig sårbart, er global styring meget viktig. Selv om global styringsteori indikerer at man gjerne finner institusjonelt samarbeid mellom offentlige og private aktører, har jeg ikke funnet noe institusjonalisert samarbeid mellom Arktisk Råd og olje- og gassindustrien. Derimot har jeg klargjort at det finnes høy grad av uformelt samarbeid mellom aktørene. Spesielt gjennom uformelle dialoger, møter og konferanser, samt samarbeid med frivillige standardiseringsinitiativer trer dette frem. Jeg har videre påpekt at slik uformelle samarbeid kan både skape klare styringseffekter, samt bidra til å etablere normer, som igjen kan bidra til styringseffekter. Siden disse uformelle mekanismene står sentralt, er det viktig å inkorporere uformelle mekanismer i et mer helhetlig rammeverk når man skal analysere global styring eller samarbeid mellom offentlige og private aktører. Siden global styringsteori via multiaktørteorier ikke kan forklare global styring i Arktis, har den kanskje overvurdert utstrekningen av slikt samarbeid. Siden regionen, og miljøstyring i forbindelse med olje- og gassaktiviteter er noe unikt, er det også mulig at en i global styringsteori har overvurdert utstrekningen av tilsvarende institusjonalisert samarbeid i lignende regioner eller problemområder. Men siden Arktis bare er en "case", er det vanskelig å konkludere noe for sikkert. Men uansett synes det viktig å inkludere uformelle samarbeidsmekanismer mellom offentlige og private aktører i global styringsteori. Ved å evaluere og analysere disse uformelle styringsmekanismene kan vi avdekke om slike samarbeid kan være mer effektive enn formelle samarbeid eller om de kan føre til slike formelle samarbeid. Vi kan også muligens observere flere samarbeid mellom næringslivsaktører og offentlige aktører hvis vi inkluderer flere slike former for uformelle samarbeid.

\section{Litteraturliste}

Abbott, K W \& Snidal, D 1998, 'Why States Act Through Formal International Organizations, The Journal of Conflict Resolution, vol. 42, no.1, pp. 3-32.

Arctic Climate Impact Assessment (ACIA) 2004. Impacts of a Warming Arctic: Arctic Climate Change Assessment. Cambridge University Press, Cambridge.

Arctic Offshore Oil and Gas Guidelines 2009, Arctic Council, Protection of the Arctic Marine Environment (PAME), http://arctic-council. org/filearchive/Arctic\%20Offhsore\%20Oil\% 20and\%20Gas\%20 Guidelines\%202009.pdf, accessed 30/6-2010.

Arctic Oil and Gas 2007, Arctic Monitoring and Assessment Programme (AMAP), Oslo.

Bäckstrand, K 2006, Multi-Stakeholder Partnerships for Sustainable Development: Rethinking Legitimacy, Accountability and Effectiveness', European Environment, vol. 16, pp 290-306.

Borgerson, SG 2008, 'Arctic Meltdown - The Economic and Security Implications of Global Warming', Foreign Affairs, vol. 87, nr. 2, pp. 67- 77.

Boström, M \& Hallström, KT 2010 'The Fragile Authority of MulitStakeholder Standard Setting'. Paper prepared for the SGIR conference Stockholm.

Bull, B 2010, 'Rethinking Multilateralism: Global Governance and Public - Private Partnerships in the UN' in M Ougaard. \& A Leander (red.)Business and Global Governance, Routledge, London.

Börzel, T \& Risse, T 2005, 'Public-Private Partnerships - Effective and Legitimate Tools of International Governance?' in E Grande, \& LW Pauly, 2005, Complex sovereignty: reconstituting political authority in the twenty-first century, University of Toronto Press, Toronto.

Commission of Global Governance 1995, Our Global Neighborhood, Oxford University Press, New York.

Corell, H, Corell, R et al 2010, 'Arctic Governance in an Era of Transformative Change: Critical Questions, Governance Principles, Ways Forward- Report of the Arctic Governance'.

Djelic M-L \& Sahlin-Andersson, K 2006, Transnational Governance: Institutional Dynamics of Regulation, Cambridge University Press, Cambridge.

Finnemore, M \& Sikkink, K 1998, “International Norm Dynamics and Political Change“, International Organization, vol. 52, no. 4, pp. 887-917.

Glomsrød, S and Aslaksen I 2006, 'The Economy of the North', Statitisk Sentralbyrå, Oslo/Kongsvinger.

Held, D \& McGrew, A 2002, Governing Globalization - Power, Authority and Global Governance, Polity Press, Cambridge.

Ilulissat Declaration, http://www.oceanlaw.org/downloads/arctic/ Ilulissat_Declaration.pdf (accessed 07.06.2010).

Intergovernmental Panel on Climate Change (IPCC) 2007, Climate Change: The Physical Science Basis. Contribution of Working Group I to the Fourth Assessment Report of the Intergovernmental Panel on Climate Change, Cambridge University Press, Cambridge.

Karns, MP \& Mingst, KA 2004, International Organizations - The Politics and Processes of Global Governance, Lynne Rienner Publishers, Boulder, CO.

Keohane, RO \& Nye, JS 2000, 'Introduction' in JS Nye \& JD Donahue (reds.), Governance in a Globalizing World, Brookings Institution Press, Washington D.C.

Koivurova, T, Molenaar, EJ 2009, 'International Governance and Regulation of the Marine Arctic: Overview and Gap Analysis', World Wildlife Fund International Arctic Programme, Oslo.

Nowlan, L 2001, Arctic Legal Regime for Environmental Protection, IUCN, Gland, Switzerland and Cambridge. 
Offerdal, K 2007, 'Oil, gas and the environment' in SO Stokke \& G Hønneland, International Cooperation and Arctic Governance, Routlegde, London.

Ougaard, M \& Leander, A 2010, Business and Global Governance, Routledge, London.

Reinicke, W Deng, F et al 2000, Critical Choices; The United Nations, networks, and the future of global governance, International Development Research Center, Ottawa.

Rosenau, JN 2005, 'Goverance in the twenty-first century' in R. Wilkinson (ed.), 2005, The Global Governance Reader, Routledge, London.

Stokke, OS 2007, 'A legal regime for the Arctic - Interplay with the Law of the Sea Convention' Marine Policy, vol. 31, no 4, pp. 402-408.

Streck, C 2002, 'Global Public Policy Networks as Coalitions for Change' in DC Esty \& MH Ivanova, Global Environmental Governance: Options \& Opportunities, New Haven, Yale School of Forestry $\&$ Environmental Studies.

Tuomela, R 1993, 'What is Cooperation', Erkenntnis, vol. 38, no 1, pp. 87-101.

United Nations General Assembly Towards Global Partnerships: Cooperation Between the United Nations and All Relevant Partners, in Particular the Private Sector, Report of the Secretary-General, 9 October 2001, available online at http://www.un.org/partnerships / Docs/partnershipreport_a-56-323.pdf.

United States Geological Survey 2008 (USGS) Fact Sheet http://pubs. usgs.gov/fs/2008/3049/fs2008-3049.pdf, accessed 21/6-2010.

Wigell, M 2008, 'Multi-Stakeholder Cooperation in Global Governance', Helsinki Process Publication Series, nr. 7, Finnish Institute of International Affairs
Young, OR 1997, Global governance: drawing insights from the environmental experience, MIT, Cambridge, Mass.

Young, OR 2009, 'The Arctic in Play: Governance in a Time of Rapid Change', The International Journal of Marine and Coastal Law, vol. 24, no.2, pp. 423-442.

\section{Intervjuer}

International Association of Oil and Gas Producers, OGP/Heide Mairs/Exxon Mobil, Utført 30/7-2010

Parker, James G. Independent Oil and Gas Environmental Consultant, Utført 10/7-2010

Reiersen, Lars Otto. Director Arctic Monitoring and Assessment Programme (AMAP), Arctic Council Working Group, Utført 05/72010

Young, Oran. Arktis- ekspert og styringsteoretiker, utført 21/7-2010

\section{Noter}

1. Ilulissat Declaration 2008

2. Se mer-Arctic Marine Shipping Assessment 2009 Report - Arctic Council/PAME

3. "Gold rush" terminologien er ofte brukt- se http://news.bbc. co.uk/2/hi/business/4354036.stm

4. Også kalt BP-oljeutslippet og oljekatastrofen i Mexico-golfen

5. Deler av de forskjellige nasjonale lovene om miljø i Arktis er beskrevet i "A Summary of Legal Instruments and National Frameworks for Arctic Marine Conservation“, utgitt av CAFF og Arktisk Råd

\section{'Statskundskabens Klassikere'}

er en ny bogserie, der kort og præcist guider dig igennem de væsentligste bidrag til vores moderne forståelse af politik. Få ren besked om, hvordan Arendt forsøgte at genskabe menneskets politiske eksistens, hvilken epokegørende betydning Rawls retfærdighedsprincipper har haft og få overblikket over Schmitts tese om liberalismen og demokratiet som hinandens modsætninger.

Nye, spcendende titler $i$ serien

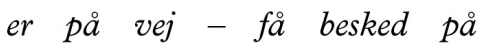
Djoef-forlag.dk.
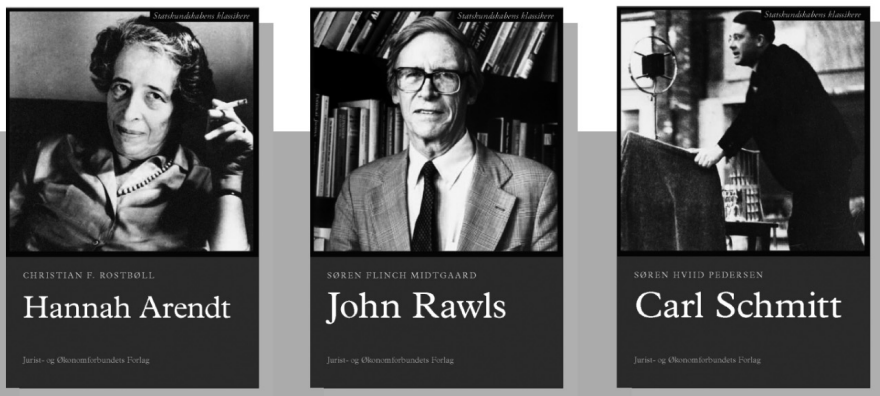